\title{
TEOLOGI ASY'ARIYAH DAN KLAIM PEMBELAANNYA TERHADAP MAZHAB SALAF
}

\section{ASY'ARIYAH THEOLOGY AND ITS CLAIMS TO DEFENSE THE SALAF $M A Z H A B$}

\author{
Muhammad Istiqamah \\ Sekolah Tinggi Ilmu Islam dan Bahasa Arab (STIBA) Makassar \\ Email: muhammadistiqamah@stiba.ac.id \\ Syandri \\ Sekolah Tinggi Ilmu Islam dan Bahasa Arab (STIBA) Makassar \\ Email: syandri@stiba.ac.id
}

\section{Keywords: \\ theology, Asy'ariyah, defense, Salaf Mazhab}

This study aims to explain the opinions of theology of Asy'ariyah and its comparison with the Salaf mazhab. This research is qualitative descriptive research with library research techniques that use normative theological approache. The results of this study show that Asy'ariyah in various discussions of the creed has its own opinions of Islamic creed, ranging from the first obligation of a mukallaf, the meaning of tawhid, al-imān, asmā' wa sifat, kalam Allah,

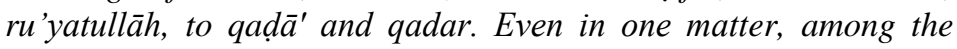
Assyrians had different views. As for the comparative study between Asy'ariyah theology and salaf mazhab found a considerable difference between the two. Both in the matter of the first obligation as a mukallaf, regarding kalamullah, the attributes of Allah, destiny, or the matter of faith, so that the defense of the salaf mazhab echoed by Asy'ariyah is only an unproven claim.

Kata kunci:

teologi, Asy'ariyah, pembelaan, Mazhab Salaf

\section{ABSTRAK}

Penelitian ini bertujuan untuk menjelaskan pendapat-pendapat teologi Asy'ariyah dan perbandingannya dengan mazhab salaf. Penelitian ini merupakan penelitian deskriptif kualitatif dengan teknik studi pustaka (library research) yang menggunakan pendekatan teologis normatif. Hasil penelitian ini menunjukkan bahwa Asy'ariyah dalam ragam pembahasan akidah memiliki pendapat-pendapat pemikiran akidah Islam tersendiri, mulai dari kewajiban pertama seorang mukallaf, makna tauhid, al-imān, asma ${ }^{\prime}$ wa șifat, kalam Allah, ru'yatullāh, hingga qad̄̄' dan qadar. Bahkan dalam satu masalah, di antara para tokoh Asy'ariyah memiliki pandangan yang berbeda-beda. Adapun setelah dilakukan studi komparatif antara teologi Asy'ariyah dengan mazhab salaf ditemukan perbedaan yang cukup banyak di antara keduanya. Baik dalam masalah kewajiban pertama sebagai seorang mukallaf, berkenaan kalamullah, sifat-sifat Allah, takdir, maupun masalah iman, sehingga pembelaan terhadap mazhab salaf yang digaungkan oleh Asy'ariyah hanyalah klaim yang tidak terbukti.

Diterima: 17 September 2021; Direvisi: 15 November 2021; Disetujui: 9 Desember 2021; Tersedia online: 10 Desember 2021 
How to cite: Muhammad Istiqamah, Syandri. "Teologi Asy'ariyah dan Klaim Pembelaannya Terhadap Mazhab Salaf', NUKHBATUL 'ULUM: Jurnal Bidang Kajian Islam Vol. 7, No. 2 (2021): 298-317. doi: 10.36701/nukhbah.v7i2.415.

\section{PENDAHULUAN}

Permasalahan terkait teologi dalam kajian pemikiran Islam akhir-akhir ini kembali mengemuka ke ruang publik, khususnya dalam kajian tentang sifat-sifat Allah swt. Tampak terjadi diskursus dan dialektika yang cukup alot antara kelompok yang menetapkan sifat-sifat tersebut (al-Musititūn) dan kelompok yang menegasikannya (al-Nufät). Seperti ungkapan "Terserah yang di atas", "Tuhan tertawa" dan lainnya dianggap sebagai bentuk kekafiran meskipun yang mengucapkannya tidak bertujuan keluar dari agama Islam ${ }^{1}$. Diskusi tentang hal ini telah ada sejak awal-awal sejarah Islam, tepatnya pada masa awal generasi tabiin saat munculnya Jahmiyah, setelah itu diikuti oleh Muktazilah dan kemudian di masa berikutnya muncul Asy'ariyah ${ }^{2}$.

Jahmiyah dengan sangat ekstrem menegasikan semua nama dan sifat Allah. Sejak saat itu, perdebatan antara al-Musititūn dengan al-Nufät tidak pernah usai. Namun, dalam rentang sejarah, Jahmiyah dan Muktazilah sebagai kelompok ideologi, tidak eksis lagi di masa ini dengan para tokoh dan basis massanya. Berbeda halnya dengan kelompok Asy'ariyah dan Maturidiyah sebagai "saudara kembarnya" yang mewakili corak pemikiran kalangan al-Nufät tersebut. Dengan demikian, dalam kajian ini terdapat dua masalah inti permasalahan yang diangkat dan dibedah oleh penulis, yaitu; pertama, bagaimana pandangan Asy'ariyah pada bahasan-bahasan teologi; kedua, bagaimana perbandingan teologi Asy'ariyah dengan mazhab Salaf.

Pada pengkajian pokok permasalahan di atas, penelitian ini menggunakan metode kepustakaan (library research) dalam membedahnya melalui pendekatan teologis normatif. Studi kepustakaan dapat diterjemahkan sebagai serangkaian kegiatan yang berkenaan dengan metode pengumpulan data perpustakaan dengan cara membaca, mencatat, menganalisis dan mengolah bahan penelitian kepustakaan ${ }^{3}$, sementara pendekatan teologis normatif digunakan dalam memahami agama secara harfiah, atau dapat diartikan sebagai upaya memahami agama dengan menggunakan kerangka ilmu ketuhanan yang bertolak dari suatu keyakinan bahwa wujud empiris dari keagamaan dianggap sebagai yang paling benar dibandingkan dengan yang lainnya ${ }^{4}$.

Berkenaan dengan subtansi pengkajian di atas, ditemukan beberapa penelitian terdahulu yang relevan, di antaranya: (1) Hadi Rafitra Hasibuan pada tahun 2017 dalam penelitiannya yang berjudul Aliran Asy'ariyah (Kajian Historis dan Pengaruh Aliran Kalam Asy'ariyah) ${ }^{5}$ secara umum menarasikan sejarah perkembangan Asy'ariyah dimulai dari Abu Hasan al-Asy'ari dan murid-muridnya yang mengembangkan teologi Asy'ariyah; (2) Muhammad Syarif Hasyim dalam kajiannya yang berjudul Al-Asy'ariyah (Studi tentang Pemikiran al-Baqillani, al-Juwaini, al-

${ }^{1}$ Muhammad Istiqamah, "Kritik Teologi Salafiyah Terhadap Ahli Kalam Dalam Memahami Sifat-Sifat Allah," NUKHBATUL 'ULUM: Jurnal Bidang Kajian Islam 6, no. 1 (2020): 77-104.

${ }^{2}$ Abdullāh bin Muhammad al-Ghunaimān, Syarah Kitab Tauhid Shahih Bukhari vol. I (Riyāụ: Dār Al-'Āsimah, 2007). h. 6-7

${ }^{3}$ Mestika Zed, Metode Peneletian Kepustakaan (Yayasan Obor Indonesia, 2004). h. 3-4.

${ }^{4}$ M Yatimin Abdullah, Studi Islam Kontemporer (t.t: Amzah, 2006). h. 151

${ }^{5}$ Hadi Rafitra Hasibuan, "Aliran Asy'ariyah (Kajian Historis Dan Pengaruh Aliran Kalam Asy'ariyah)," Jurnal Ilmiah Al-Hadi 2, no. 2 (2018): 433-41. 
Ghazali) ${ }^{6}$ secara khusus menguraikan beberapa tokoh sentral mazhab Asy'ariyah yaitu al-Baqillani, al-Juwaini, dan al-Ghazali yang dianggap telah meletakkan asas teologi Asy'ariyah, sehingga berbeda dengan Muktazilah; (3) Adnin dan Muhammad Zein pada kajiannya yang berjudul Epistemologi Kalam Asy'ariyah dan al-Maturidiyah, ${ }^{7}$ berkesimpulan bahwa hadirnya pemikiran Asy'ariyah dan Maturidiyah adalah hasil dari ketidakpuasan keduanya terhadap pemikiran yang diusung oleh Muktazilah, sekaligus tergambarkan bahwa pemikiran Maturidiyah memberikan otoritas kepada akal lebih besar daripada Asy'ariyah; (4) Bahrul Ulum berupaya mengkaji dinamika kemunculan dan perkembangan ilmu kalam dalam lingkup sunni. Ia menyebutkan bahwa tiga mazhab pemikiran Sunni masuk dalam kajian ini, yakni Asy'ariyah, Tahawi dan Maturidi; dan (5) Ilhamuddin dan Muhammad Lathief pada kajiannya meneliti tentang teologi Islam dengan berbagai dinamika dan tema-tema pokoknya serta membandingan teologi Islam klasik dan modern. Kajian tersebut lebih ditekankan pada komparasi antarmazhab dalam teologi Islam, terkhusus pada terma al-Imān wa al-Kufr, al-Wa'd wa al-Wa'̀̄d, af'āl al-'Ibād, Kalām Allāh dan Ru'yat $A l l a h^{8}$. Selain itu, penelitian ini juga membandingkan metodologi mazhab teologi Sunni dengan Muktazilah dalam beberapa terma kajian pada lingkup sifat dan perbuatan Allah. Kemudian, penelitian ini juga mengkaji kritik Ibnu Taimiyah terhadap Kalam Sunni. Konsep al-Kasb dalam faham Asy'ariyah menjadi fokus kritik. Menurut Ibnu Taimiyah, teori al-Kasb ini bukannya menengahi antara Jabariyah dan Qadariyah, melainkan lebih mendekati kaum Jabariyah";

Berdasarkan hasil telaah di atas, secara asumtif belum ditemukan penelitian secara spesifik yang menyoal ragam pendapat dalam teologi Asy'ariyah dan perbandingannya dengan mazhab Salaf. Oleh sebab itu, penelitian ini bertujuan untuk memberikan gambaran tentang pandangan Asy'ariyah pada bahasan-bahasan teologi dan perbandingannya dengan mazhab Salaf. Ragam pendapat teologi Asy'ariyah pada penelitian ini akan dijelaskan dengan porsi yang relatif lebih besar, tidak lain agar rincian pendapat-pendapat teologi Asy'ariyah dapat diketahui dengan lebih detail.

\section{PEMBAHASAN}

\section{Siapakah Asy'ariyah?}

Menurut Sulthan al-Umairi ${ }^{10}$, sejak awal munculnya, Asy'ariyah merepresentasikan sebuah manhaj baru yang berbeda dengan mazhab Salaf meskipun pada awalnya ingin membelanya. Abū al-Hasan al-Asy'arī (w. $324 \mathrm{H}$ ) melandaskan pemikiran-pemikiran teologinya pada manhaj dan metode Ibnu Kullāb (w. $240 \mathrm{H})^{11}$.

${ }^{6}$ Muhammad Syarif Hasyim, “Al-Asy’ārīyah (Studi Tentang Pemikiran Al-Baqillani, AlJuwaini, Al-Ghazali)," HUNAFA: Jurnal Studia Islamika 2, no. 3 (2005): 209-24.

${ }^{7}$ Adnin Adnin and Muhammad Zein, "Epistemologi Kalam Asy'ariyah Dan Al-Maturidiyah," Al-Hikmah: Jurnal Theosofi Dan Peradaban Islam 2, no. 1 (2020).

${ }^{8}$ Ilhamuddin Ilhamuddin and Muhammad Lathief Ilhamy Nasution, "Teologi Islam Warisan Pemikir Muslim Klasik," (Medan: Perdana Publishing, 2017).

${ }^{9}$ Bahrul Ulum, "Dinamika Ilmu Kalam Sunni," EL-BANAT: Jurnal Pemikiran Dan Pendidikan Islam 6, no. 2 (2016): 22-33.

${ }^{10}$ Salah seorang pengajar di Universitas Ummul Qura Makkah Al-Mukarramah https://uqu.edu.sa/saomairi/App/CV, “السيرة الذاتية سلطان العميري," n.d.

${ }^{11}$ Sultān Al-Umairī, Iḍāt F̄̄ Al-Tahrīr Al- 'Aqad̄̄, 1st ed. (Markaz Tafakkur Li Al-Buhūs̀ wa AlDirāsāt, 2014). h. 125 
Hal ini diungkapkan sendiri oleh al-Syahrastānī (w. 548 H) dalam al-Milal wa alNihal, "Hingga pada masa Abdullah bin Sa'̄̄d al-Kullābī, Abū al-'Abbās al-Qalanis̄̄ dan al-Hāris̀ bin As'ad al-Muhāsibī, mereka sebenarnya termasuk generasi Salaf, namun mereka ikut berkecimpung dalam dunia ilmu kalam dan membela akidah Salaf dengan argumentasi-argumentasi kalamiyah dan ușūliyah.... Dan al-Asy'ārī ikut bergabung dengan kelompok ini. Ia membela pandangan-pandangan mereka dengan metode ilmu kalam. Dan itulah yang menjadi mazhab Ahli sunah waljamaah. Dan kemudian predikat 'al-Sifātiyah' beralih kepada kelompok Asy'ariyah"12.

Dari ketiga tokoh yang disebutkan sebelumnya, Ibnu Kullāb ${ }^{13}$ menjadi tokoh yang sangat penting tatkala membersamai perjalanan Abū al-Hasan al-Asy'arī dalam menemukan metode yang menurutnya sangat memuaskan dalam mengurai perdebatan teologi yang sedang ramai pada saat itu. Ibnu Taimiyah pun memberikan gambaran tentang Ibnu Kullāb sebagai berikut, “Abu Muhammad Abdullah bin Saīd bin Kullāb al-Bașrī menulis beragam kitab untuk membantah Jahmiyah, Muktazilah dan selain mereka. Beliau merupakan Ahli Kalam dari kelompok al-Sifatiyah. Metodenya cenderung dan dekat dengan metode mazhab Ahl al-Hadïs wa al-Sunnah. Namun, ada jenis bidah pada metode tersebut karena ia menetapkan adanya sifat-sifat Allah pada Zat-Nya tapi tidak menetapkan perkara-perkara ikhtiyāriyah yang ada pada zat-Nya tersebut. Akan tetapi, beliau memiliki bantahan kepada Jahmiyah -para penegasi (Nufāt) sifat-sifat Allah dan sifat Al-'Uluw dengan beragam dalil serta argumentasi dalam pemaparannya yang membuktikan kelebihan beliau" ${ }^{14}$. Pandangan-pandangan teologi Ibnu Kullāb banyak dikutip oleh Abū al-Hasan al-Asy'arī dalam kitabnya, "Maqālāt al-Islamiyyīn." Mulai dari Asmā̄' wa Silfāt, Sifat Al-Kalām dan Al-Qur'an secara khusus, kemudian al-Ru'yah, al-Qad̄à' wa al-Qadar hingga masalah al-Imān, sehingga hampir seluruh pandangan Ibnu Kullāb diikuti oleh Al-Asy'arī. ${ }^{15}$. Oleh karena itu, Asy'ariyah bisa disebut juga sebagai Kullābiyah ${ }^{16}$.

Abū al-Hasan al-Asy'arī melalui dua atau tiga fase dalam perjalanannya telah mencari "kebenaran." Secara singkat, beberapa kalangan berpendapat bahwa beliau

${ }^{12}$ Muḥammad Ibn Abd al Al-Syahrastān̄i, "Al-Milal Wa Al-Nihal” Jilid I, (Kairo: Musțāfā alBab al-Halabi Wa Awlāduhū, 1967). h. 91.

${ }^{13}$ Keyakinan awal Ibnu Kullab tentang Sifat-sifat Allah bersumber dari Muktazilah yang menegasikan sifat-sifat Allah yang berkaitan dengan kehendak dan qudrah-Nya (Sifat ikhtiyariyah). Namun setelahnya ia menyelisihi Muktazilah mengenai sifat-sifat Allah yang lainnya (Al-Shifat AlDzatiyah). Ibnu Kullab menetapkan sifat-sifat tersebut sedangkan Muktazilah secara mutlak menegasikan semua sifat Allah. Karena itulah, Ibnu Kullab menjadi orang pertama yang mengerucutkan penegasian Sifat hanya pada Sifat Ikhtiyariyah. Juga membuat pendapat baru tentang Kalamullah, bahwa Kalam Allah adalah sebuah makna yang ada dalam diri Allah (ma'nan qa'imun binafsihi). Tentang Al-Qur'an ia menyebutnya bukan Kalam-Nya secara hakiki, tapi merupakan hikayat tentang Kalam-Nya. Namun ia tetap menetapkan sifat Al-'Uluw.Ibnu Hazm, Al-Faśl Fī Al-Milal Wa AlAhwä'wa Al-Nihal, Vol, IV (Beirūt, vol. 5 (Maktabah al-Salām al-Alamiyah, n.d.). h. 77.

${ }^{14}$ Taqiyuddīn Abu al-Abbās Ahmad bin Abdu al-Halīm Ibnu Taimiyyah, Majmū' Al-Fatāwa, Juz 12 (Madīnah: Majma' al-Mālik Fahd, 1995). h. 366

${ }^{15}$ Hanya beberapa hal yang rinci dari pandangan-pandangan tersebut yang tidak diaminkan olehnya. Sebagai contoh kecil, pandangannya tentang Al-Qur'an. Ibnu Kullab mengatakan bahwa ia adalah hikayat (Al-Hikayah) tentang Kalam-Nya. Sedangkan Al-Asy'ārī tidak menyetujui hal itu dan lebih memilih bahwa Al-Qur'an adalah refleksi (Al-'Ibarah) tentang Kalam-Nya. Abdurraḥmān AlMạ̣mūd, Mauqif Ibn Taimiyah Min Al-Asyā' irah, 1st ed. (Dammām: Dār Ibn Al-Jauzī, 1435 H.). h. 396-405.

${ }^{16}$ Abdurraḥmān Al-Maḥmūd, Mauqif Ibn Taimiyah Min Al-Asya'irah, h. 393. 
melalui tiga fase yakni fase pertamanya berfaham Muktazilah, fase kedua mengikuti pemikiran-pemikiran Ibnu Kullāb, dan fase yang ketiga dan terakhir kembali pada manhaj Salaf. Namun, sebagian ulama menganggap "kembalinya" tersebut tidak secara komprehensif. Hal ini dikarenakan masih ada beberapa pemahamannya yang mengikuti pemahaman Ibnu Kullāb. ${ }^{17}$

Menurut al-Syahrastānī dalam al-Milal wa al-Nihal dan Ibnu Hajar dalam Lisān alMizān, Abū al-Ḥasan al-Asy'arī dalam kitabnya al-Ibānah masih menggunakan pendapat-pendapat dan metode Ibnu Kullā ${ }^{18}$. Hal ini juga menjadi pendapat Ibnu Furāk bahwa uṣūl mereka berdua masih sama ${ }^{19}$. Hal ini terlihat dalam beberapa pandangan dalam masalah sifat ikhtiyāriyah seperti sifat nuzūl dan sifat al-majì' dijelaskan sebagai sesuatu yang tidak mengalami perpindahan dan pergerakan ${ }^{20}$. Begitu juga dengan sifat ikhtiyāriyah yang lain seperti al-Gad̄āb ditakwil sebagai keinginan Allah untuk mengazab mereka dan al-Riḍa sebagai keinginan Allah untuk memberikan mereka nikmat ${ }^{21}$.

Sedangkan bagi kalangan yang mengatakan bahwa beliau hanya melalui dua fase seperti pendapat Ibnu Taimiyah yang menyebutkan bahwa fase pertamanya berpaham Muktazilah dan fase keduanya mengikuti metode Ibnu Kullāb dengan condong pada mazhab ahli sunah waljamaah dan intisāb kepada Imam Ahmad bin Hanbal secara umum.

Pada fase kedua, baik yang berpendapat dua fase maupun tiga fase, pandanganpandangan Abū al-Hasan al-Asy'ari banyak diikuti oleh ulama yang datang setelahnya, seperti Abū al-Hasan al-Thabarī (w. 380 H), Abū Bakar al-Bāqillānī (w. 403 H), Ibnu Fūrak (w. 406 H) dan Abū Ishāq al-Isfirayīnī (w. 418 H). Terkhusus tiga nama terakhir disebut sebagai perintis-perintis awal tersebarnya faham Asy'ariyah secara lebih luas ${ }^{22}$. Dari penjelasan ini bisa disimpulkan definisi Asy'ariyah secara singkat, yakni mereka yang mengikuti Abū al-Ḥasan Alī bin Ismā'̄̄l al-Asy'ārī ketika ia di atas jalan dan metode Ibnu Kullāb dalam i'tiqua $d^{23}$.

\section{Kewajiban Pertama Seorang Mukalaf}

Sebagian besar kitab-kitab Asy'ariyah yang membahas permasalahan teologi dengan corak ilmu kalam memulai pembahasannya dengan memberikan pengantar tentang mantik, akal dan yang berkaitan dengan alam. Lalu pembahasan setelahnya tentang Ilähiyyāt yang membahas masalah-masalah yang berkaitan dengan penetapan wujud Allah dan penjelasan bahwa selain Allah adalah muhdas dan makhluk. Pembahasan ini banyak menyanggah kalangan dahriyyah, falāsifah dan ateismaterialis. Lalu kemudian membahas tentang keesaan sang Khaliq dan sifat-sifat-

\footnotetext{
${ }^{17}$ Abdul Qadīr Aṭha' Șufī, Al-Asy'ārīyyah (Madīnah Al-Munawwarah, 2018), h. 8

${ }^{18}$ Ibnu Ḥajar Syihabuddīn Abū Al-Fadhl Aḥmad bin Alī bin Muḥammad bin Ḥajar, Lisan AlMizan (Beirūt: Muassasah al-A'lamī, 1971). h. 291.

${ }^{19}$ Ibnu Taimiyah, Naqud Asās Al-Taqdīs (Makkah: Mathba'ah al-Hukumah, 1391 H), h. 37-41

${ }^{20} \mathrm{Abū}$ Al-Ḥasan Al-Asy'arī, Risālah Ahl Al-Śagr (Cairo: Mathba'ah al-Taqaddum, 1987), h. 73-

74

${ }^{21}$ Ibid,h. 74

${ }^{22}$ Abdul Azīz bin Marzūq al-Ṭarifī, Al-Khurrasaniyyah Fi Syarh 'Aqidat Al-Raziyyain (Riyāḍ: Maktabah Dār al Minhaj, 2016), h. 44-48

${ }^{23}$ Abdul Qadīr Ațha' Șufī, Al-Asy'ariyyah, h. 1
} 
$\mathrm{Nya}^{24}$. Pada bahasan tersebut, kitab-kitab Asy'ariyyah telah mengurai beberapa masalah yang berkaitan dengan kewajiban pertama seorang mukalaf (awwalu wäjibin 'alā al-mukallaf), dalāl hudūis al-ajsām, makna tauhid dan juga masalah-masalah yang lainnya, sehingga bahasan-bahasan pengantar dalam kitab-kitab teologi Asy'ariyah muatannya tampak demikian ${ }^{25}$.

Asy'ariyah meyakini bahwa kewajiban pertama seorang hamba jika sudah sampai pada masa balig dan mendapat beban taklif adalah berpikir atau bernalar tentang keberadaan Allah Azza wa Jalla dengan melihat dan memperhatikan alam semesta ${ }^{26}$. Istilah yang digunakan sangat beragam. Ada yang menyebutnya al-Ma'rifah ${ }^{27}$, yang lain menyebutnya al-Nażar atau al-Qaṣdū Ilā al-Nażar dan ada yang menyebutnya dengan al-Syakk ${ }^{28}$. Kemudian para tokoh Asy'ariyah sendiri berselisih pendapat bagi orang awam yang tidak mampu bernalar pada tiga pendapat, kafir, bermaksiat dan mukmin, al-Sanūsī memilih pendapat pertama ${ }^{29}$. Ini juga menjadi pilihan al-Baijūrī dalam Syarah Jauharah al-Tauhīd, ia menyebut, "Maka seorang muqallid (ikut-ikut saja) adalah kafir" ${ }^{\prime 30}$.

\section{Makna Tauhid}

Tauhid versi Asy'ariyah bisa dilihat dalam tiga ungkapan berikut: ${ }^{31}$

1. "Wāhidun fi Żătihì, Là Qasima Lahu," artinya, bahwa satu dalam zat-Nya, tidak terbagi-bagi). Kalimat ini dijelaskan dengan ungkapan, "Lā Yanqasim (tidak terbagi), Là Yatajazza', La Yataba'ad (Tidak menjadi bagian-bagian), Lā Yata'addad (Tidak berbilang), Là Yatarakkab (Tidak tersusun)." Maksud dari ungkapan ini mereka ingin menegasikan Șifāt Żātiyah dan atau Șifät Khabariyah, bahwasanya Allah tidak berdiri dengan zat-Nya sendiri, tidak berada di atas arasy dan bahwa Allah tidak di arah atas. Hal ini dikarenakan semua yang bisa dilihat dalam pikiran mereka adalah suatu zat yang tersusun dan terangkai, dan itulah makna Jismiyyah, Tahayyuż dan Jihhah yang mereka negasikan. Fakhruddīn AlRāzī dengan jelas mengatakan, "Kullu Mutahayyizìn fahuwa munqasim, wa kullu

\footnotetext{
${ }^{24}$ Abdurraḥmān Al-Mạ̣mūd, Mauqif Ibn Taimiyah Min Al-Asyā'irah, 1st e,. h. 840

${ }^{25} \mathrm{Abū}$ Bakr Muḥammad ibn Ṭayyib ibn al-Baqillānī, Al-Tamhīd (Bairūt: al-Maktabah alSyarqiyyah, 1958). h. 22-25

${ }^{26}$ Keyakinan ini dibangun di atas permasalahan yang lain, yaitu tentang cara dan proses manusia dalam memperoleh Al-Ma'rifah. Ibnu Taimiyah menyebut ada tiga pendapat dalam permasalahan ini. Pertama, Ma'rifatullah tidak didapatkan kecuali dengan bernalar (Al-Nazhar). Ini merupakan pendapat kebanyakan Muktazilah dan Asya'irah. Kedua, Al-Ma'rifah telah ditanamkan oleh Allah dalam hati manusia tanpa harus bernalar, meneliti maupun dengan melakukan sebab yang lainnya. Al-Ma'rifah telah ada secara otomatis. Pendapat ini adalah pendapat mayoritas Shufiyah dan Syiah. Ketiga, AlMa'rifah bisa terjadi secara otomatis dan bisa juga diperoleh dengan bernalar. Pendapat ini merupakan pendapat jumhur kaum muslimin.Ibnu Taimiyah, Dar'u Al-Ta'āruḍ Baina Al-Aql Wa Al-Naql jilid 7 , (Riyāḍ: Al Jāmiah Al Imām Muhammad Ibn Sa'ūd Al Islāmiyah, 1991). h. 352-354

${ }^{27}$ Al-Qāộ̄ Abū Ya'lā', Kitāb Al-Mu’tamad F̄̄ Ușūluddīn (Bairūt: Dār al-Masyriq, 1974). h. 21

${ }^{28}$ Hazm, Al-Fashl Fi Al-Milal Wa Al-Ahwa'wa Al-Nihal, Vol.4, h.74

${ }^{29}$ Ismail bin Musā bin Uṡmīn al-Hāmid̄̄, Hawas̄̄ 'Ala Syarh Al-Kubrā Li Al-Sanusī Al-Tilmisān̄̄ (Miṣr: Maṭbah Musțafā al Bān̄̄ al-Halabī wa Auladuhū, 1936), h. 39.

${ }^{30}$ Al-Baijurī, Tuhfat Al-Murīd 'Alū Jauharat Al-Tauhīd, 1st ed. (Al-Qāhirah: Dār al-Salām, 2002), h. 32

${ }^{31}$ Abū Bakr Muhammad ibn al-Ḥasan Ibnu Furāk, Mujarrad Maqalat Al-Syekh Abī Al-Hasan Al$A$ 'syārī (Bairūt: Dār al-Masyriq, 1987). h. 55.
} 
munqasimin fahuwa laisa bi ahad." Artinya, bahwa semua yang berada di dalam suatu arah maka ia pasti bisa terbagi, dan setiap yang bisa terbagi maka ia bukanlah satu ${ }^{32}$. Dalam keyakinan Asy'ariyah, jika Allah memiliki sifat maka pasti akan berbilang, terbagi, tersusun dan seterusnya. Jika dikatakan bahwa Allah memiliki tangan maka akan menjadi dua, yakni Allah dan tangan. Jika dikatakan Allah memiliki wajah dan tangan maka akan menjadi tiga, yakni Allah, wajah dan tangan. Setiap ditambah sifat, maka Allah akan semakin berbilang jumlahnya karena tersusun dan terangkai dengan sifat-sifat itu. Oleh karenanya, sifat Allah yang paling spesial menurut Asy'ariyah adalah Al-Qidam, untuk menegasikan semua sifat yang muncul dan menetapkan bahwa Allah itu hanya satu pada zatNya.

2. "Wāhidun fì Sifātihī, Là Syabiha Lahū," artinya, bahwa satu dalam sifat-Nya, tidak ada yang serupa dengan-Nya. Maksud dari ungkapan ini adalah untuk menegasikan sifat, karena menetapkan sifat Allah akan menjurus ke tasybīh pada makhluk dalam pandangan mereka. Hal ini juga dinegasikan dengan cara tafwìd dan takwīl. Menurut mereka, metode tafwìd inilah yang ditempuh oleh Salaf. Sedangkan takwīl ditempuh oleh Khalaf atau generasi setelah Salaf. Inilah yang dimaksud dalam ungkapan Asy'ariyah yang masyhur, "Tariqah Al-Salaf Aslam, wa Tariqah Al-Khalaf A'lam wa Ahkam," Artinya, bahwa metode salaf lebih selamat, sedangkan metode khalaf lebih baik dan lebih metodologis.

3. "Wāhidun fì Af'alihì, Là Syarika Lahū," artinya, bahwa satu dalam perbuatanperbuatan-Nya, tidak ada sekutu bagi-Nya). Inilah makna yang difahami dari Tauhid Rububiyah, bahwa Allah yang menciptakan segala sesuatu dan mengaturnya. Namun, inilah inti makna tauhid menurut Asy'ariyah yang menjadi tujuan diutusnya para Rasul. Sebenarnya ungkapan tersebut ditujukan Asy'ariyah untuk Muktazilah yang meyakini bahwa sebagian Maujūdāt bukan ciptaan Allah seperti perbuatan hamba.

\section{Al-Asmā}

Pandangan Asy'ariyah dalam masalah ini diringkas pada dua poin berikut:

1. Pendapat jumhur Asy'ariyah yang sejalan dengan pendapat jumhur $\mathrm{Salaf}^{33}$,

a. Al-Asmā' Al-Husnā adalah tauqüfiyyah.

b. Asmāullāh Laisat Jāmidah, yakni nama-nama tersebut punya makna yang sangat luas dan juga makna yang menunjukkan sifat-sifat Allah. Hal ini dikarenakan sebagian menganggap bahwa nama-nama Allah tidak memiliki makna.

c. Asmāullāh tidak terbatas pada angka sembilan puluh sembilan.

2. Sebagian Asy'ariyah menyelisihi jumhur Salaf pada beberapa sub bahasan AlAsmā' Al-Husnā.

1) Sebagian Asy'ariyah berkesimpulan bahwa ada nama yang secara bahasa bisa menjadi nama Allah, meskipun tidak berdasarkan dalil seperti Al-Qadìm atau Al$\dot{Z} \bar{a} t^{34}$.

\footnotetext{
${ }^{32}$ Fakhruddin Al-Rāzī, Asās Al-Taqdīs (al-Qāhirah: Maktabah al-Kullīyāt al-Azhāriyyah, 2001).
} h. 17.

${ }_{33}$ Abdurraḥman Al-Mạ̣mūd, Mauqif Ibn Taimiyah Min Al-Asyā 'irah, h. 938.

${ }^{34}$ Abū Ḥāmid al-Gazālī, Al-Maqșad Al-Asmā' F̄̄ Syarh Al-Asmā' Al Husnā (Bairūt: Dār ibn Hazm, n.d.). h. 165. 
2) Kitab-kitab Asy'ariyah menjelaskan bahwa Asmāullāh juga menunjukkan makna sifat. Namun, makna sifat yang dimaksud sesuai dengan paham yang diyakini oleh Asy'ariyah. Seperti Al-'Alī, para ulama Asy'ariyah menakwilkannya dengan ketinggian kedudukan atau kemuliaan dan tidak menetapkan ketinggian zat Allah di atas makhluk-Nya ${ }^{35}$.

3) Asy'ariyah menegasikan nama Allah, "Al-Nūr" dan mereka takwīl-kan dengan Al-Hādi atau pemberi cahaya langit ${ }^{36}$.

\section{Al-Ṣifät}

Kajian mengenai sifat Allah menjadi salah satu titik perbedaan dan perdebatan antar beragam kelompok semenjak munculnya firkah-firkah dalam Islam, terutama setelah munculnya Jahmiyah.

Pandangan Asy'ariyah tentang sifat bisa dilihat pada beberapa poin berikut:

1. Asy'ariyah sepakat menetapkan tujuh sifat al-'Aqliyyah yakni, Al-Ilm, Al-Qudrah, Al-Irādah, Al-Hayāh, Al-Kalām, Al-Sam'u, Al-Bașar ${ }^{37}$. Mereka juga menetapkan dua puluh sifat dengan pembagian berikut: ${ }^{38}$

a. Tujuh Șifāt 'Aqliyyah yang disebut Șifāt Al-Ma'āni (Al-Ilmu, Al-Qudrah, AlIrādah, Al-Hayah, Al-Kalām, Al-Sam'u, Al-Bașar).

b. Tujuh Șifät Al-Ma'nāwiyah, yakni tujuh șifāt Al-Ma'āni yang terjadi pada masa

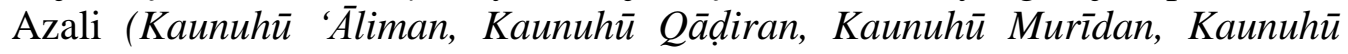
Hayyan, Kaunuhū Mutakalliman, Kaunuhū Samī’an, Kaunuhū Bașīran).

c. Lima Sifāt Salbiyah yaitu Al-Qidam, Al-Baqā', Al-Qiyām bi Al-Nafs, Mukhalafah Li Al-Hawādis, Al-Wahdaniyyah).

d. Satu Sifat Al-Nafsiyyah, yakni Al-Wujūd.

2. Asy'ariyah sepakat menegasikan Șifāt Ikhtiyariyyah yang diyakini oleh para ulama Salaf sesuai dengan zahirnya, ini yang mereka sebut dengan Hulul Al-Hawādis. Seperti sifat Al-Riḍā, Al-Gaḍab, Al-Farh, Al-Maj̄̄', Al-Nuzūl, Al-Ityān dan yang lainnya. Adapun hal tersebut adalah inti mazhab Ibnu Kullāb yang diikuti oleh AlAsy'ari dan pengikutnya, atau jika ditetapkan, maka sifat-sifat tersebut ditetapkan terjadi Azāliyah Qadīmah. Nuzūl-Nya, Maj̄̄'-Nya, Ityān-Nya, Farh-Nya, GhaḍabNya, Ridh-Nya dan yang semisal ini adalah Qadīm Azāli ${ }^{39}$.

3. Sifat Khabariyah seperti Al-Wajh, Al-Yadain, Al-'Aīn, Al-Yamīn, Al-Qabdah, AlSāq, Al-Qadam, Al-Așhabì' dan yang lainnya terdapat dua pendapat:

a. Mutaqaddimūn Asy'ariyah menetapkannya secara umum seperti pendapat para ulama Salaf. Al-Wajh, Al-Yadain, Al-'Ain ditetapkan oleh Al-Asy'ari, AlBāqillān̄i, Ibnu Fūrok, Al-Baihaqī dan selain mereka. Adapun sifat Al-Yamīn, Al-Qabḍah, Al-Qadam, Al-Ashabì' ini ditakwil seperti Abū al-Hasan Al-Ṭabarī di mana ia mengatakan, "Allah melihat tanpa mata," sehingga bisa dikatakan

${ }^{35}$ Ibid, h. 108.

${ }^{36}$ Fakhruddin Al-Razi, Asās Al-Taqdīs, h. 79-80

${ }^{37}$ Abī Manșūr Abdul Qāhir Al-Baghdādī, Ushuluddin (Istambul: Matba'ah al-Daulah, 1928), h.

90

38 Abū Abdillāh Muḥammad bin Yūsuf al-Sanūsī, Al-Manhaj Al-Sadīd Fi Syarh Kifāyat AlMurīd, (Al-Jazāir: Dār al-Hudā, n.d.), h. 214-216

39 Abū Al-Ḥasan Al-Asy'arī, Maqalat Al-Islāmiyyīn (Beirūt: Maktabah Al Așriyyah, 1990), h. 250 . 
bahwa Mutaqaddimun Asy'ariyah menetapkan sifat-sifat ini secara umum, karena yang ditetapkan hanya tiga sifat yakni, Al-Wajh, Al-Yadain, Al- 'Ain ${ }^{40}$.

b. Muta'akhkhirīn Asy'ariyah menakwil sifat-sifat ini. Seperti Abī Manșūr Abdul Qāhir Al-Baghdādī dan Al-Juwain̄̄ juga generasi Asy'ariyah setelahnya, sehingga hal inilah yang menjadi akidah mazhab Asy'ariyah sekarang, meskipun mereka menarasikan dua pendapat ini; pertama, dengan takwīl dan ini yang dirajihkan; kedua, ditetapkan dengan syarat harus di-tafwi ${ }^{41}$.

4. Sifat Al-Istiwā', pendapat Asy'ariyah dalam masalah ini terbagi menjadi tiga:

a. Abū al-Hasan al-Asy'arī menetapkannya dengan cara tafwì istiwā' adalah suatu perbuatan yang Allah lakukan di arasy yang diberi nama istiwā', adapun Ibnu Kullāb dan al-Qalānisī mengatakan bahwa Allah di atas arasy tanpa adanya sentuhan ${ }^{42}$.

b. Abu al-Ma'âlī al-Juwainī dan Abū Hāmid al-Gazālī menakwil istiwā' dengan istila', al-Qahr dan al-Galabah, yang artinya, menguasai, mengalahkan dan menang ${ }^{43}$.

c. Sedangkan para generasi akhir Asy'ariyah seperti Abī Manșūr Abdul Qāhir AlBaghdādī menolak takwīl istiwā' dengan istila', al-Qahr dan al-Galabah, ia lebih memilih menakwilnya sebagai Al-Mulk atau kerajaan. ${ }^{44}$

5. Sifat al-'Uluw, pendapat mayoritas Asy'ariyah hingga hari ini menolak sifat ketinggian zat Allah di atas seluruh makhluk-Nya ${ }^{45}$.

6. Mengenai sifat Al-Kalām, mazhab Asy'ariyah dari awal oleh para mutaqaddimūn hingga para muta'akhkhirīn-nya tetap meyakini bahwa kalam Allah adalah $A z \bar{a} \bar{l} \bar{\imath}$ dan disebut sebagai Al-Kalām Al-Nafsi, tanpa suara dan huruf seperti yang dijelaskan oleh Al-Baqillānī dalam kitab Tamhīd dan al-Inșăf $f^{46}$.

\section{Kalamullah dan Al-Qur'an}

Bagian ini sebenarnya sudah masuk dalam bahasan pandangan Asy'ariyah tentang Al-Șifät di atas, namun perlu dirinci pada sub bahasan khusus agar tergambar secara lebih jelas. Mazhab Ibnu Kullāb dan Abū al-Hasan al-Asy'arī serta pengikut mereka pada bahasan tentang Kalamullah dianggap sebagai mazhab baru. Pandangan mereka terhadap masalah ini merupakan ciri khas mazhab Asy'ariyah, dan keyakinan inilah yang seseorang bisa disebut sebagai seorang Asy'arī atau bukan. Hal ini dikarenakan dalam pembahasan yang lain, tidak hanya Ibnu Kullāb dan Abū al-Hasan yang mempunyai pendapat khusus dalam satu masalah tertentu. "Apa yang dikatakan oleh mereka berdua, dikatakan juga oleh selain mereka berdua. Baik dari Ahli sunah dan Ahli Hadis atau dari selain mereka. Berbeda dengan pandangan Ibnu Kullāb terkait masalah al-Kalām, yang diikuti oleh al-Asy'ari. Ibnu Kullāb tidak didahului oleh

\footnotetext{
${ }^{40}$ Abū Al-Hasan Al-Asy’ari, Risalah Ahl Al-Ṡagr, h. 225-226

${ }^{41}$ Abī Manșūr Abdul Qāhir Al-Baghdādī, Ușūluddīn, h. 108-114

${ }^{42} \mathrm{Ab} \overline{1}$ Manșūr Abdul Qāhir Al-Baghdādī, Ușūluddīn, h. 112-113

${ }^{43}$ al-Imām al-Gazālī, Al-Iqtișād F̄̄ Al-I'tiqāed, 1st ed. (Al-Qāhirah: Dār al-Bașāir, 2009), h. 38.

${ }^{44} \mathrm{Ab} \bar{i}$ Manșūr Abdul Qāhir Al-Baghdādī, Ușūluddīn, h. 112-113

${ }^{45}$ Sayyid Syarīf 'Alī Ibn Muhammad al-Jurjānī, Syarh Al-Mawāqif Lì Al-Qāḍ̂̀ 'Adu Al-Dīn Abdurraḥmān Al- 'Ijī, 3rd ed. (Bairūt: Dār Kutub Al Ilmiah, 1998), h. 29.

${ }^{46} \mathrm{Abu}$ Bakr Muhammad ibn Țayyib ibn al-Baqillani, Al-Tamhīd, h. 283
} 
seorang pun, bahkan tidak disetujui pula oleh tokoh-tokoh firkah yang lain." ${ }^{47}$ Berikut rincian pandangan Asy'ariyah tentang Kalamullah dan Al-Qur'an:

1. Bahwa ia adalah sebuah makna yang ada dalam diri yakni, Ma'nan Qā'imun Bi Al-Nafs), tanpa suara dan tanpa lafaz. Inilah yang disebut dengan Kalam Al-Nafsi. Berikutnya mereka tidak setuju jika dikatakan bahwa Kalamullah memiliki huruf dan suara. Bahwasanya ia adalah Qadìm Azālì dan Qaim pada zat Allah seperti Hayāt-Nya dan Ilmu-Nya, karena itu ia tidak berkaitan dengan kehendak dan qudrah-Nya, serta tidak berbicara ketika Ia berkendak ${ }^{48}$.

2. Al-Qur'an yang berbahasa Arab adalah refleksi dari Kalamullah, ia adalah makhluk, yang dibawa oleh Jibril atau Muhammad saw., atau Allah adakan di udara dan Lauh Al-Mahfüz. Bahkan dengan tegas Al-Baqillānī menyebut bahwa Al-Qur'an adalah perkataan Jibril ${ }^{49}$. Dari sini tidak berbeda dengan apa yang diyakini oleh Muktazilah seperti yang diungkapkan sendiri oleh Syekh Muhammad Sa'̄̄d Ramadhān Al-Buṭhī, "Adapun jumhur kaum muslimin, ahlussunah waljamaah mereka mengatakan kami tidak mengingkari yang dikatakan oleh Muktazilah, kami pun mengatakan demikian dan kami sebut dengan Kalām Lafżì. Kita semua sepakat bahwa ia adalah sesuatu yang muhdas dan tidak berbarengan dengan zat Allah, karena kemuhdasannya tersebut. Namun, kami menetapkan sesuatu di balik itu, yakni sifat yang terjadi dalam diri yang diungkapkan dengan lafaz. Dengan demikian, disinilah Muktazilah berbeda dengan jumhur, di mana mereka tidak menyandarkan pada Allah sifat qadìm dengan pengertian Kalām Al-Nafs. ${ }^{, 50}$

\section{Al-Qad̄à'wa Al-Qadar}

Pandangan Asy'ariyah tentang Al-Qad̄a 'wa Al-Qadar di mana secara khusus dalam masalah kemampuan seorang hamba untuk berbuat lebih dekat ke Jabariah. Adapun rinciannya bisa diperhatikan dalam beberapa poin berikut:

\section{Bahasan Al-Qadar}

\section{a. Al-Hikmah dan Ta'līl}

Asy'ariyah menegasikan adanya hikmah dan alasan pada perbuatan-perbuatan Allah. Mereka ungkapkan, "Sesungguhnya Ia menciptakan seluruh makhluk dan mengadakan semua yang ada bukan karena adanya suatu alasan dan bukan karena adanya suatu sebab," mereka juga mengatakan, "Bahwasanya Ia Tabāraka wa Ta'āla melakukan ini hanya karena semata-mata berkehendak dan menyalurkan keinginan." 51

b. Al-Tahsiñ dan Al-Taqbīh

Dalam pandangan Asy'ariyah sesuatu yang baik atau kebaikan adalah yang dianggap baik oleh syariat saja, begitu pun keburukan. Akal tidak punya porsi dalam menilai sesuatu yang baik atau buruk. Contohnya, jika Allah menghukum seorang ahli

\footnotetext{
${ }^{47}$ Syaikh al-Islām Aḥmad ibn al Ḥal̄im Ibnu Taimiyah, Al-Tis 'iniyyah, 1st ed. (Riyāḍ: Maktabah al Ma'ārif li al-Nasyr wa al Tauz̄̄, 1999). h. 149-288.

${ }^{48} \mathrm{Abū}$ Bakr Muhammad ibn Ṭayyib ibn al-Baqillani, Al-Tamhīd, h. 283.

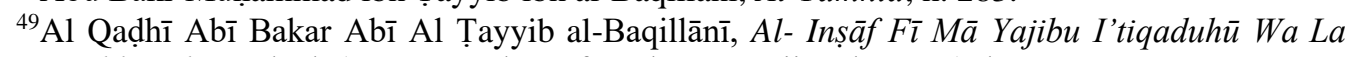
Yajuzu Al-Jahlu Bihī, 2nd ed. (t.cet: Dār al-Tayfīq Al Namūżajiyyah, 2000), h. 147-148

${ }^{50}$ Muhammad Sa'īd Ramaḍān Al-Būṭị, Kubra Al-Yaqìniyyāt Al-Kauniyyah (Damaskus: Dār alFikr, 1982). h. 125-126

${ }^{51}$ Abdul Karīm al Syahristānī, Nihāyat Al-Iqdām (al-Qāhirah: Maktabah al-Ṡaqāfah al Diniyyah, 2009), h.297.
} 
tauhid dan para Nabi-Nya dengan neraka maka perbuatan Allah tersebut adalah baik. Begitu pun sebaliknya ${ }^{52}$.

c. Mas'alat Al-Zulm

Kezaliman dalam pandangan Asy'ariyah adalah melakukan sesuatu di luar wilayah wewenangnya. Atas dasar ini, apapun yang Allah lakukan dalam wilayah kerajaanNya adalah bukan kezaliman. Misalnya jika Allah mengazab orang-orang yang taat maka itu bukan kezaliman, sebaliknya jika Allah memuliakan orang-orang kafir dan ahli maksiat maka itu juga bukan kezaliman. Ini menurut mereka sah-sah saja Allah lakukan, karena semuanya berada dalam wilayah wewenang dan kerajaan-Nya ${ }^{53}$.

d. Taklīf Mā Là Yuțāq

Asy'ariyah berpandangan bahwa bisa dan sah-sah saja jika Allah memberi beban taklif diluar kemampuan seorang hamba. Misalnya, jika Allah memberi beban taklif kepada kita untuk harus berjalan di atas wajah atau kepala kita maka itu bisa saja Allah lakukan $^{54}$.

\section{Perbuatan Hamba dan Al-Kasb}

Asy'ariyah berpandangan bahwa seorang hamba melakukan perbuatannya dengan kemampuan yang diberikan oleh Allah, tapi kemampuan tersebut tidak memberikan pengaruh atau Qudrah Ghairu Muasisirah. Allah memberikan kemampuan tersebut pada seorang hamba tapi tidak berpengaruh dalam melahirkan sebuah perbuatan. Sedangkan hamba dinisbahkan padanya perbuatan tersebut hanya sebagai majaz, perbuatannya itu disebut sebagai $A l-K a s b^{55}$.

\section{Al-Imān}

Pandangan Asy'ariyah dalam masalah Al-Imān cenderung pada mazhab Murji'ah. Secara umum sangat mirip dengan pendapat mereka pada masalah Al-Kalam, di mana mereka membatasinya pada Kalām Al-Nafsĭ, dan bukan lafaz. Sedangkan pada pembahasan Al-Imān, mereka memaknainya hanya pada Al-Ma'rifah dan Al-Tasंdìq, dan tidak memasukkan perkataan serta perbuatan dalam makna iman. Namun, tidak semua mengatakannya seperti ini, sebagian pandangan kelompok Asy'ariyah dalam bahasan ini terbagi ke dalam tiga pendapat berikut: ${ }^{.6}$

1. Bahwa iman adalah perkataan, perbuatan dan pembenaran, sama seperti pandangan para ulama Salaf. Namun, hanya sedikit kalangan Asy'ariyah yang berpendapat seperti ini.

2. Sebagian yang lain berpendapat seperti Murjiah Al-Fuqāhā bahwa Al-Imān hanya

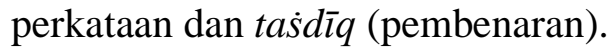

3. Sebagian yang lainnya mengatakan bahwa Al-Imān hanyalah Al-Ma'rifah atau AlTaśd $q$ dalam hati, ini merupakan pandangan Abū al-Ḥasan al-Asy'arī dan

\footnotetext{
${ }^{52} \mathrm{Al}$ Imām al- Haramain Al Juwain̄̄, Kitāb Al-Irsyād Ilā Qawāti' Al-Adillah Fū Uś̄ul Al-I'tiqād, 1st ed. (Al Qahirah: Maktabah Al Saqāfah al Diniyyah, 2009), h. 258.

${ }^{53}$ Ibnu Taimiyyah, Minhāj Al-Sunnah Al-Nabawiyah Fī Naqd Al-Kalām Al Syiah Al-Qadariyyah Vol. I (Riyadh: Jāmiah al-Imām Muḥammad ibn Saūd al-Islāmiyyah, 1986), h. 232.

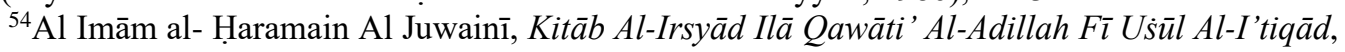
h. 226

${ }^{55}$ Abū Abdillāh Muhammad bin Yūsuf Al-Sanūsī, Syarah Ummul Barahīn (Libanon: Dār al Kutub al- Ilmiah, 2009), h. 45.

${ }^{56}$ Abī Manșūr Abdul Qāhir Al-Baghdādī, Ușūluddīn, h. 248-249
} 
mayoritas Asy'ariyah ${ }^{57}$. Namun, di akhir dari perjalanannya, Abū al-Hasan alAsy'arī dan juga Abu Al-Ma'ālī al-Juwain̄̄ dalam masalah iman ini mengatakan

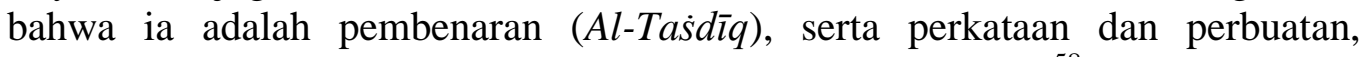
bertambah dengan ketaatan dan berkurang karena kemaksiatan ${ }^{58}$.

\section{Al-Ru'yah}

Asy'ariyah meyakini bahwa Allah dapat dilihat di hari kiamat, namun dilihat tanpa arah. Hal ini diyakini oleh Asy'ariyah lantaran menolak sifat al- 'Uluw dengan zatNya. Pandangan mereka ini kemudian terbagi ke dalam dua pendapat, yaitu:

a) Mutaqaddimūn Asy'ariyah berpandangan bahwa Allah dapat dilihat di hari kiamat dengan penglihatan mata tapi dilihat bukan ke arah tertentu. Hal ini merupakan pendapat mayoritas Asy'ariyah ${ }^{59}$.

b) Mutaakhkhirīn Asy'ariyah yang terpengaruh dengan Muktazilah seperti Al-Rāzī dan Al-Ghazālī mengatakan bahwa Allah dapat dilihat bukan dengan mata namun dengan istilah lain. Mereka sebut dengan Ziyādatu Inkisyāf dan sebagiannya menyebut Ru'yah Qalbiyah, bukan dengan mata ${ }^{60}$.

\section{Klaim Pembelaan Asy'ariyah terhadap Mazhab Salaf}

Al-Syahrastān̄i menilai bahwa perdebatan teologis yang dilakukan oleh para pendahulu Asy'ariyah seperti Abdullāh bin Saīd bin Kullāb, al-Qalanīsī, al-Muhāsibī dan Abū al-Hasan al-Asy'arī dengan beberapa firkah seperti Jahmiyah, Muktazilah dan Khawarij adalah sebagai bentuk pembelaan terhadap mazhab Salaf ${ }^{61}$. Begitu pun yang dinyatakan oleh para tokoh Asy'ariyah berikutnya seperti Abū Ishāq al-Isfirayīnī, Abū Hāmid al-Ghazālī, Fakhruddūn al-Rāzī dan tokoh-tokoh Asy'ariyah lainnya yang mana tampak merepresentasikan apa yang diyakini oleh para sahabat dan para imam setelah generasi sahabat ${ }^{62}$. Klaim ini perlu dibuktikan dengan melihat kesesuaiannya antara apa yang disimpulkan oleh para tokoh Asy'ariyah dengan teks-teks riwayat dari kalangan Salaf.

Selanjutnya, teologi Asy'ariyah pada pembahasan di atas akan dikomparasikan dengan nukilan dari para Salaf untuk melihat apakah pernyataan Asy'ariyah membela mazhab Salaf benar adanya atau ia hanyalah sebuah klaim yang tidak terbukti. Pembahasan terkait komparasi tersebut, diuraikan sebagai berikut:

1. Kewajiban Pertama Seorang Mukalaf

Asy'ariyah meyakini bahwa kewajiban pertama seorang hamba jika sudah sampai pada masa balig dan mendapat beban taklif adalah berpikir atau bernalar tentang keberadaan Allah Azza wa Jalla dengan melihat dan memperhatikan alam semesta ${ }^{63}$.

${ }^{57}$ Al-Baijurī, Tuhfat Al-Murīd 'Ala Jauharat Al-Tauhid, h. 71.

58 Abū Al-Ḥasan Al-Asy'arī, Maqalat Al-Islāmiyyīn, h.239.

${ }^{59}$ Abū Bakr Muhammad ibn Ṭayyib ibn al-Baqillani, Al-Tamhīd, h. 277.

${ }^{60}$ Abū Ḥāmid al-Ghazālī, Qawāid Al- 'Aqāid (Beirūt: Ālim al Kutub, 1985).

${ }^{61}$ Muhammad Ibn Abd al Al-Syahrastani, “Al-Milal Wa Al-Nihal” (Jilid I, Kairo: Mustafa alBabi al-Halabi Wa Awladuhu, 1967). h. 91.

${ }^{62}$ Abū Hāàmid al-Gazālī, Al-Maqshad Al-Asna F̄̄ Syarh Al-Asmā' Al Husnā, h. 157.

${ }^{63}$ Keyakinan ini dibangun di atas permasalahan yang lain, yaitu tentang cara dan proses manusia dalam memperoleh Al-Ma'rifah. Ibnu Taimiyah menyebut ada tiga pendapat dalam permasalahan ini. Pertama, Ma'rifatullah tidak didapatkan kecuali dengan bernalar (Al-Nazhar). Ini merupakan pendapat kebanyakan Muktazilah dan Asya'irah. Kedua, Al-Ma'rifah telah ditanamkan oleh Allah dalam hati 
Oleh karena hal tersebut telah terlanjur menjadi pandangan dalam teologi Asy'ariyah, maka pada akhirnya para tokoh Asy'ariyah sendiri berselisih pendapat terhadap orang awam yang tidak mampu bernalar pada tiga pendapat antara kafir, bermaksiat dan mukmin, al-Sanūsī memilih pendapat pertama ${ }^{64}$. Ibnu Hajar sendiri menilai bahwa pendapat ini adalah pendapat Muktazilah yang tersisa di kalangan Asy'ariyah ${ }^{65}$.

Sedangkan menurut Salaf, kewajiban pertama seorang mukalaf adalah syahädatain yang mengandung makna mentauhidkan dan mengesakan Allah dengan beribadah. Dalil mazhab Salaf adalah bahwa Allah diketahui dengan fitrah yang telah ditanamkan kepada seluruh manusia ${ }^{66}$. Lebih lanjut, dalam penerapannya, ketika Muadz bin Jabal ketika diutus oleh Nabi Muhammad berdakwah ke Yaman, ke negeri yang dihuni oleh Ahli Kitab. Nabi Muhammad mengatakan bahwa agenda pertamanya adalah menyerukan Ahlu Kitab untuk mengucapkan syahādatain, bukan menyuruh mereka bernalar tentang Allah untuk mengenal-Nya. Setelahnya baru diajarkan tentang kewajiban salat lima waktu.

Dalil lainnya, jika diperhatikan, Rasulullah tidak pernah memerintahkan sahabatnya untuk bernalar atau memperhatikan alam semesta sebelum mengajaknya masuk Islam. Apalagi menyuruh sahabatnya untuk ragu dulu (Al-Syak) sebelum memperoleh $A l$-Ma'rifah. Jika ada yang ingin masuk Islam hanya diperintahkan untuk melafalkan syahädatain ${ }^{67}$. Begitu pun yang dilakukan oleh para sahabat seperti Umar bin Khattab ketika ada yang datang kepadanya untuk diajarkan Islam, beliau menyuruhnya untuk bersyahadat lalu melakukan rukun Islam yang lainnya. Lalu Umar berkata kepada orang tersebut, "Jika engkau bertemu dengan Allah maka katakanlah, Umar yang memerintahkanku ini."68 Tentunya, sahabat Nabi derajatnya lebih tinggi untuk diikuti, di mana sahabat adalah generasi pertama Salaf. Perbandingan pada masalah ini telah menunjukkan perbedaan yang cukup jelas antara mazhab Salaf dan Asy'ariyah, sampai Ibnu Hajar dengan inșäf-nya mengakui pendapat kewajiban pertama seorang mukallaf adalah bernalar sebagai sisa-sisa pengaruh Muktazilah ke dalam Asy'ariyah.

\section{Sifat-sifat Allah}

Asy'ariyah memiliki dua metode dalam memahami sifat-sifat Allah, yakni dengan tafwì dan takwīl. Tafwīe menjadi pilihan para mutaqaddīmūn Asy'ariyah dan takwil menjadi pilihan para mutakhkhirinn Asy'ariyah ${ }^{69}$. Sebagai satu contoh dalam perbandingan ini adalah sifat istiwa ', Asy'ariyah dengan dua metode tadi memiliki

manusia tanpa harus bernalar, meneliti maupun dengan melakukan sebab yang lainnya. Al-Ma'rifah telah ada secara otomatis. Pendapat ini adalah pendapat mayoritas Shufiyah dan Syiah. Ketiga, AlMa'rifah bisa terjadi secara otomatis dan bisa juga diperoleh dengan bernalar. Pendapat ini merupakan pendapat jumhur kaum muslimin.Ibnu Taimiyah, Dar'u Al-Ta'arudh Baina Al-Aql Wa Al-Naql jilid 7, (Riyadh: Al Jamiah Al Imam Muhammad Ibn Sa’ud Al Islamiyah, 1991). h. 352-354

${ }^{64}$ Ismail bin Musā bin Uṡmīn al-Hāmidī, Hawas̄̄ 'Ala Syarh Al-Kubrā Li Al-Sanusī Al-Tilmisānē, h. 39 .

${ }^{65}$ Ibnu Hajar al-'Asqālanī, Fath Al-Bari Syarh Shahih Al-Bukhari (Maktabath al-Salafiyyah, n.d.), h. 70-71

${ }^{66}$ Abū Bakar Muhammad bin al-Husain al-Ajurrī al-Baghdādī, Al-Syariah Vol. II (Riyāẹ: Dār al-Waṭn, 1998), h. 815.

${ }^{67}$ Abdul Qadīr Ațha' Shufi, Al-Asy'ariyyah (Madinah Al-Munawwarah, 2018), h. 25.

${ }^{68}$ Imām al-Lalikā̄' 1 , Syarh Ușūl I'tiqād Ahlis Sunnah Wal Jamāh (Iskandariyah: Dār al-Basīirah, n.d.). h. 187.

${ }^{69}$ Abī Manșūr Abdul Qāhir Al-Baghdādī, Ușūluddīn, h. 108-114 
ragam pendapat, di antaranya bahwa Allah melakukan perbuatan di arasy yang diberi nama istiwa ', yang lain mengatakan bahwa ia adalah al-Qahr, al-Ghalabah dan alIstila' yang bermakna mengalahkan, menang dan menguasai, sedangkan yang lain mengatakannya sebagai kerajaan $^{70}$. Dua metode Asy'ariyah ini sebenarnya menunjukkan kelemahannya sendiri, sehingga akan memunculkan pertanyaan berikutnya, yang benar yang mana? tafwì d atau takwil? Lalu pertanyaan berikutnya lagi, jika takwil yang benar, lalu takwil siapa yang mau diikuti? hal ini ditengarai akan memunculkan beragam pendapat takwil dalam satu masalah seperti istiwā' ini.

Asy'ariyah sendiri justru membuat tașawwur yang keliru terhadap mazhab Salaf. Asy'ariyah menggambarkan bahwa Salaf mendiamkan masalah ini sehingga menyebut Salaf melakukan tafwīe . Seperti yang disebutkan oleh Al-Baihaqī bahwa, "Adapun istiwā' maka para Salaf dari kalangan kita, mereka tidak menafsirkannya dan tidak membicarakannya." ${ }^{71}$ Ibnu Jamā'ah ketika menyebut beberapa pendapat tentang sifat istiwā', mengatakan bahwa, "Para Salaf dan ahli takwil sepakat bahwa apa yang tidak layak untuk kemuliaan rabb adalah sesuatu yang tidak diinginkan dan tidak dimaksudkan seperti duduk dan berdiri tegak, mereka berselisih pada penentuan makna yang layak untuk Allah dengan makna-makna yang memungkinkan seperti menuju atau menguasai, sehingga Salaf lebih memilih diam, namun ditakwilkan oleh para ahli takwil dengan makna menguasai dan menang, karena ketidakmungkinannya Allah disifati dengan sifat-sifat jisim yang membutuhkan arah dan tempat."72

Al-Baijūrī terkait istiwā' ini mengatakan bahwa, "Salaf mengatakan istiwā' kami tidak mengetahuinya, sedangkan Khalaf mengatakan yang dimaksud dengannya adalah al-Istīlā' dan al-Mulk." ${ }^{, 73}$ Pertanyaannya, apakah benar pendapat para Salaf seperti itu?, dan setelah ditelusuri lebih jauh, ternyata sangat banyak ditemukan riwayat dari Salaf yang menafsirkan makna istiwā'. Bahkan, Salaf secara khusus memberikan perhatian lebih terhadap sifat istiw $\bar{a}$ ' ini karena menjadi sifat Allah yang pertama kali diingkari oleh Jahmiyah.

Salaf meyakini bahwa Allah istiwā' dengan zat-Nya di atas arasy sebagaimana disebutkan oleh Abū Nas̀r al-Sijzī bahwa, "Imam-imam kita seperti Sufyān al-Saurī, Mālik, Sufyān bin 'Uyainah, Ḥammad bin Salamah, Hammad bin Ziyād, Abdullāh bin al-Mubarak, Fuḍail bin 'Iyāḍ, Ahmad bin Hanbal dan Ishaq bin Ibrahim, mereka semua sepakat bahwa Allah dengan zat-Nya berada di atas arasy, bahwa Ia turun ke langit dunia, juga bahwa Ia marah, rida dan berbicara sesuai dengan kehendak-Nya." 74

Seperti ini juga secara khusus yang dikatakan oleh Imam Malik, "Allah berada di atas langit dan ilmu-Nya berada di setiap tempat, ilmu-Nya tidak kosong dari satu tempatpun. ${ }^{75}$ Begitupun yang disebutkan oleh al-Muzan̄̄ murid Imam Syāfi '’ $1,{ }^{76}$ Ibnu

${ }^{70}$ Ibid, h. 112-113.

${ }^{71}$ Al-Imām Al- Ḥāfiz Ab̄̄ Bakr Aḥmad ibn al Ḥusain Al-Baihaqī, Al-Asmā ’ Wa Al-Ṣifāt (Dār Al Syuhdā, 1340), h. 514.

${ }^{72}$ Badruddīn Ibnu Jamā'ah, I⿳̣̂ăh Al-Dalīl Fi Qaț’ō Hujaj Ahl Al-Ta'țīl, 1st ed. (Dimisyq: Dār Iqrā', 2008), h. 131.

${ }^{73}$ Al-Baijurī, Tuhfat Al-Murīd 'Ala Jauharat Al-Tauhid, h. 157.

${ }^{74}$ Ibnu Taimiyah, Dar'u Al-Ta'arudh Baina Al-Aql Wa Al-Naql, vol. 6, h. 250

${ }^{75}$ Ibnu Abdil Bar, Al-Tamhīd, Vol. VII, (t.cet:, t.p, 1979), h. 138.

${ }^{76}$ Ismā'̄̄l Ibn Yahyā Al-Muzan̄̄, Syarh Al-Sunnah, (t.cet, t. p, t.th), h. 75 


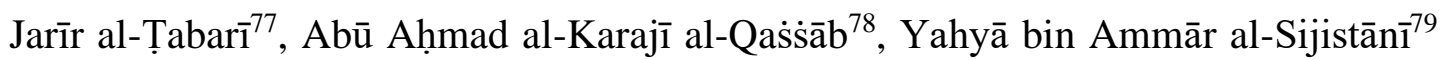
dan selain mereka menyebutkan bahwa Allah berada di atas arasy dengan zat-Nya. AlQurțūbī mengatakan bahwa, "Tidak satu pun dari Salaf yang mengingkari bahwa Allah istiw $\bar{a}$ ' di atas arasy-Nya secara hakiki, mereka hanya tidak mengetahui cara istiw $\bar{a}$ 'Nya." $" 80$

Konsekuensi dari istiwa ' ini adalah sifat al- 'Uluw al-Żatī, sebagaimana yang ditunjukkan oleh banyak riwayat dari hadis Nabi bahwa Allah berada di atas arasy, arasy sebagai atap seluruh makhluk, air di bawah arasy, langit ketujuh di bawah air, dan seterusnya sampai langit ke satu ${ }^{81}$. Bahkan, para Salaf mengatakan bahwa ini adalah ijmak seperti yang disebutkan oleh al-Auzā' ${ }^{-82}$ dan Qutaibah bin Sa'̄̄ ${ }^{83}$. Adapun makna dari istiwā' ditafsirkan oleh para Salaf dengan beragam ungkapan. Ibnu Abbās memaknainya dengan șa 'ada (naik) ${ }^{84}$. Imam Bukhari meriwayatkan dari Abu al-'Āliyah makna istiwa ' dengan irtafa'a (naik) dan juga dari mujahid dengan makna meninggi di atas arasy ${ }^{85}$. Ibnu Jarīr al-Ṭabarī meriwayatkan makna istiwā' dari alRabī' bin Anas dengan naik menuju langit ${ }^{86}$. Imam al-Mufassir Abū al-Futūh Sulaim bin Ayyūb al-Rāzī menukil dari Abu 'Ubaidah makna istiwā' dengan 'alā (meninggi) dan selainnya dengan istaqarra (menetap) ${ }^{87}$. Al-Baghawi menukil dari al-Kalbī dan Muqātil bahwa makna istiwā' dengan istaqarra (menetap) dan dari Abū 'Ubaidah dengan șa'ada (naik) ${ }^{88}$.

Semua riwayat ini menunjukkan bahwa Salaf membahas maknanya, tidak melakukan tafwì dan tidak mendiamkannya, apalagi melakukan takwil. Berbeda dengan apa yang disebutkan oleh para tokoh Asy'ariyah. Bahkan, menurut Asy'ariyah, jika memaknai istiwā' dengan pemaknaan zahir bahasa Arab seperti yang dilakukan oleh para Salaf di atas sebagai bentuk pemahaman Musyabbihah dan Mujassimah ${ }^{89}$. Di mana secara tidak langsung menuduh para Salaf tadi sebagai Musyabbihah dan Mujassimah yakni kelompok yang menyerupakan Allah dengan makhluk dan menilai Allah memiliki jisim atau tubuh. Oleh karena itu, apa yang dilakukan oleh Asy'ariyah terkhusus dalam masalah sifat-sifat Allah bukanlah pembelaan terhadap mazhab Salaf, justru mencela apa yang dipahami oleh para Salaf dan menuduh para ulama yang berpaham seperti itu dengan tuduhan-tuduhan yang tidak layak.

\footnotetext{
${ }^{77} \mathrm{Ibnu}$ Jarīr Al Ṭabarī , “Tafsir Al Ṭabarī,” Juz 20, h. 659-660.

${ }^{78}$ Al-Żahabī, Al- 'Uluw Lì 'Ālì Al-Gaffār (Riyāḍ: Maktabah Aḍwā al Salaf, 1995), h. 236.

${ }^{79}$ Ibid, h. 564.

${ }^{80} \mathrm{Abī}$ Abdillāh Muhammad Ibn Aḥmad Ibn Abī Bakr Al-Qurțubī, Tafsīr Al-Qurțubī Jilid 9 (Beirūt: Muassasah al-Risālah, 2006), h. 239

${ }^{81}$ Imām al-Lalikā'̄i, Syarh Ușūl I'tiqād Ahlis Sunnah Wal Jamāh, h. 362.

${ }^{82} \mathrm{Al}-\mathrm{Imām}$ Al- Ḥāfiz Abī Bakr Aḥmad ibn al Ḥusain Al-Baihaqī, Al-Asmā' Wa Al-Ṣifāt, h. 865.

${ }^{83} \mathrm{Al}-\mathrm{Z} a \mathrm{ahab} \overline{1}, A l-$ 'Uluw Lì 'Āll̄ Al-Gaffär, h. 470.

${ }^{84} \mathrm{Al}$-Imām Al- Ḥāfiz Abī Bakr Aḥmad ibn al Ḥusain Al-Baihaqī, Al-Asmā' Wa Al-Ṣifāt, Jilid 2, h. 310 .

${ }^{85}$ Muhammad Ibn Ismā'îl Al-Bukhāī, Șahīh Al-Bukhārī, Vol.9 (Dar Ul-Hadith, 1978), h. 51.

${ }^{86}$ Ibnu Jarī Al Ṭabarī , "Tafsir Al Ṭabarī,” Juz I, (Beirut: Daar Al Fikr, 1954), h. 429.

${ }^{87} \mathrm{Al}-\dot{Z} \mathrm{Z} a \mathrm{hab} \overline{1}, A l-' U l u w$ Lì 'Ālì Al-Gaffār, h. 528.

${ }^{88} \mathrm{Al}-\mathrm{Imām}$ Muhyi al-Sunnah Abī Muḥammad al Husain Ibn Mas'ūd Al-Baghawī, Ma'alim AlTanzil Juz III, (cet;I, Riyāẹ: Dār al-Ṭayyibah, 1989), h. 235.

${ }^{89}$ Saifuddīn al-Amidī, Gāyāt Al-Marām Fi 'Ilm Al-Kalām (Al-Qāhirah: Lajna al-Turās̀ alIslāmiyah, 1981), h. 137-138.
} 


\section{Takdir}

Asy'ariyah dalam masalah takdir yang terkait dengan perbuatan Allah menyebutkan bahwa Allah melakukan segalanya tanpa adanya hikmah dan alasan tertentu, tapi hanya sekedar menyalurkan keinginan dan kehendak ${ }^{90}$. Para Salaf meyakini bahwa apa yang dilakukan oleh Allah adalah karena hikmah yang besar dan tujuan-tujuan yang mulia yang karenanya Allah berbuat. Pada hal tersebut, Salaf bahkan telah ijmak $^{91}$. Terkait dengan perbuatan hamba, Asy'ariyah menyebutnya sebagai Kasb, yakni adanya kemampuan melakukan perbuatan namun tidak memiliki pengaruh dalam melahirkan perbuatan tersebut ${ }^{92}$. Asy'ariyah dalam hal ini bersikap moderat antara Jabariyah dan Qadariyah, padahal jika dilihat teori al-Kasb yang diusung oleh Asy'ariyah, maka ditemukan sama dengan apa yang diyakini oleh Jabariyah, sebab mereka mengatakan bahwa hamba tidak memiliki pengaruh dalam melahirkan perbuatan. Sama dengan Jabariyah yang mengatakan bahwa hamba tidak memiliki kemampuan apa-apa dalam melakukan perbuatan ${ }^{93}$.

\section{Iman}

Mayoritas Asy'ariyah berpendapat bahwa iman hanyalah tasidiq atau pembenaran dalam hati ${ }^{94}$. Ini berbeda dengan apa yang disebutkan oleh para Salaf bahwa iman adalah pembenaran (tașdīq), perkatan ( $q a u l$ ), dan perbuatan ('amal) seperti yang disebutkan oleh al-Hasan al-Bashrī, Zaid bin Aslam, Sufyān al-Ṡaurī, Mālik bin Anas, Wakī' bin al-Jarrah, al-Auza'̄̄, Syuraik, Abū Salamah, Hammād bin Salamah, Hammād bin Zaid, Imām Syāfí'̄̄, Imām Aḥmad bin Ḥanbal dan masih banyak lagi yang disebutkan riwayatnya oleh al-Lālika'ì dalam kitabnya Syarh Ușūl I'tiqād Ahl al-Sunnah wa al-Jamā'ah ${ }^{95}$.

Pendapat mayoritas Asy'ariyah yang menyatakan bahwa iman sebatas perkataan tanpa perbuatan atau hanya sekadar al-Ma'rifah, maka hal ini lebih dekat kepada pemahaman Murjiah dan Jahmiyah daripada ke pemahaman Salaf, sebagaimana yang disebutkan oleh Wakī' bin al-Jarrāh, guru dari Imam Syafi' ${ }^{\prime}{ }^{96}$. Dari perbandingan ini ditemukan pula akan banyaknya ketidaksesuaian antara pendapat-pendapat teologi Asy'ariyah dengan apa yang dipahami oleh Salaf. Bahkan, Asy'ariyah lebih dekat kepada kelompok pemikiran yang lain seperti Muktazilah dalam masalah kewajiban pertama sebagai seorang mukalaf dan masalah Kalam, pemikiran Jahmiyah dalam masalah Sifat, pemikiran Jabariyah dalam masalah takdir, dan Murjiah dalam masalah Iman, yang mana kesemuanya tampak bertentangan dengan mazhab Salaf.

Salah satu sebab ketidaksesuaian tersebut adalah karena cara interaksi Asy'ariyah dengan nukilan-nukilan dari Salaf, ditemukan bahwa Asy'ariyah tidak berpatokan sepenuhnya dengan semua nukilan tersebut dan bahkan tidak berusaha mengumpulkan semua riwayat yang sahih dari Salaf. Adapun yang dilakukan hanyalah menukil riwayat dari Salaf yang tampaknya sesuai dengan kesimpulan paham Asy'ariyah dan

${ }^{90}$ Abdul Karīm al Syahristānī, Nihāyat Al-Iqdām (al-Qāhirah: Maktabah al-Ṡaqāfah al Diniyyah, 2009), h. 297.

${ }^{91}$ Taqiyuddīn Abu al-Abbās Ahmad bin Abdu al-Halīm Ibnu Taimiyyah. Majmu' Al-Fatāwa, jilid 8, h. 485 .

${ }^{92}$ Abū Abdillāh Muhammad bin Yūsuf Al-Sanūsī, Syarah Ummul Barahīn, h. 45.

${ }^{93}$ Abdul Az̄̄z bin Marzūq al-Ṭarifî, Al-Khurrasaniyyah Fi Syarh 'Aqidat Al-Raziyyain, h. 220.

${ }^{94}$ Al-Baijurī, Tuhfat Al-Murīd 'Ala Jauharat Al-Tauhid, h. 71.

${ }^{95}$ Imām al-Lalikā'̄̄, Syarh Ușūl I'tiqād Ahlis Sunnah Wal Jamāh, h. 745-747.

${ }^{96}$ Imām al-Lalikā'̄', Syarh Ușūl I'tiqād Ahlis Sunnah Wal Jamāh, h. 846. 
melupakan riwayat lainnya yang begitu banyak dan bertentangan dengan pokok mazhab Asy'ariyah ${ }^{97}$. Seperti misalnya dalam masalah sifat-sifat Allah, Asy'ariyah hanya menukil teks umum dari riwayat Salaf untuk menyimpulkan bahwa Salaf mentafwìd dalam masalah ini, dan sengaja tidak mengambil puluhan riwayat lain yang menunjukkan bahwa para Salaf menetapkan makna untuk sifat-sifat ilahiah dengan tidak menyerupakan-Nya dengan sifat makhluk ${ }^{98}$.

Hal ini sangat jauh jika dibandingkan dengan apa yang dilakukan oleh para Imam seperti Ibnu Khuzaimah dalam kitabnya, "al-Tauhīd," Abdullah bin Ahmad bin Hanbal dalam kitabnya, "al-Sunnah," al-Lālikā'̄̄ dalam kitabnya, "Syarah Ușūl I'tiqād Ahlu Sunnah wa al-Jama'ah," Ibnu Baththah dalam kitabnya, "al-Ibānah," serta alĀjurrī dalam kitabnya, "al-Syarī'ah," dan masih banyak lagi. Mereka kumpulkan semua teks riwayat dari para Salaf, menyusunnya dengan baik satu persatu, dan berusaha menjelaskan maknanya. Tidak menutup-nutupi atau lebih menampakkan yang satu daripada yang lainnya. Dengan demikian, hal ini menegaskan bahwa merekalah para imam yang lebih berhak merepresentasikan mazhab Salaf, bukan Asy'ariyah.

\section{KESIMPULAN}

Hasil dari penelitian ini menunjukkan bahwa teologi Asy'ariyah memiliki pendapat-pendapat pemikiran akidah Islam tersendiri, mulai dari kewajiban pertama sebagai seorang mukalaf, makna tauhid, al-īmān, asmā' wa sifāt, kalam Allah, rukyatullah, hingga qad̄à' dan qadar. Pendapat teologi Asy'ariyah ini bahkan keberadaannya muncul beragam dalam satu masalah yang sama, sehingga, dalam menetapkan pendapat mana yang menjadi mazhab resmi teologi Asy'ariyah dalam masalah tersebut tampak cukup membingunkan. Berikutnya ditemukan banyak ketidaksesuaian antara pendapat-pendapat teologi Asy'ariyah dengan apa yang dipahami oleh para Salaf. Baik dalam masalah kewajiban pertama sebagai seorang mukalaf, Kalamullah, sifat-sifat Allah, takdir, maupun masalah iman yang kesemuanya tampak tidak sejalan bahkan bertentangan dengan mazhab Salaf.

Penelitian ini pada esensinya mengerucut pada satu kesimpulan penting, dikarenakan baik Salafiyah maupun Asy'ariyah sepakat bahwa mazhab Salaf dianggap sebagai poros rujukan dalam pandangan-pandangan teologi. Dua kelompok tersebut sama-sama mengklaim membela mazhab Salaf. Oleh karena itu, klaim tersebut harus dibuktikan dengan studi komparatif, yakni dengan membandingkannya dengan apa yang diyakini oleh generasi Salaf. Kajian-kajian yang ada, semestinya diarahkan kepada sebuah pembuktian yang otentik, bukan sekadar justifikasi dan tuduhantudahan yang tidak berdasar terhadap kelompok lain yang berseberangan. Dengan demikian, narasi-narasi yang terbangun berikutnya dan muncul di ruang publik bisa lebih terkontrol dan terkendali.

\section{DAFTAR PUSTAKA}

Abdul Az̄̄z bin Marzūq al-Ṭarifì. Al-Khurrasaniyyah Fi Syarh 'Aqidat Al-Raziyyain. Riyāḍ: Maktabah Dār al Minhaj, 2016.

\footnotetext{
${ }^{97}$ Sulțān Al-Umairī, Idạât F̄̄ Al-Taḥrīr Al- 'Aqadī. h. 143.

${ }^{98}$ Faiṡāl Ibn Qazār al-Jāsim, Al-Asyā'irah Fì Mizān Ahl Sunnah, 1st ed. (Kuwait: al- Mabarratu al-Khairiyyah li Umūr al-Qur'ān wa al-Sunnah, 2007), h. 89-143.
} 
Abdul Karīm al Syahristānī. Nihāyat Al-Iqdām. al-Qāhirah: Maktabah al-Ṡaqāfah al Diniyyah, 2009.

Abdul Qadīr Ațha' Shufi. Al-Asy'ariyyah. Madinah Al-Munawwarah, 2018.

Abdullāh bin Muhammad al-Ghunaimān. Syarah Kitab Tauhid Shahih Bukhari. Riyāḍ: Dār Al-'Āsisimah, 2007.

Abdullah, M Yatimin. Studi Islam Kontemporer. Amzah, 2006.

Abdurrahman Al-Mahmud. Mauqif Ibn Taimiyah Min Al-Asyā'irah. 2nd ed. Riyāḍ: Maktabah al-Rusd, 1995.

Abdurraḥmān Al-Mạ̣mūd. Mauqif Ibn Taimiyah Min Al-Asya 'irah. 1st ed. Dammām: Dār Ibn Al-Jauzī, n.d.

Ab̄̄ Abdillāh Muḥammad Ibn Aḥmad Ibn Abī Bakr Al-Qurțubī. Tafsīr Al-Qurțubī. Beirūt: Muassasah al-Risālah, 2006.

Abī Manșūr Abdul Qāhir Al-Baghdādī. Ușūluddīn. Istambul: Matba'ah al-Daulah, 1928.

Abū Abdillāh Muḥammad bin Yūsuf al-Sanūsī. Al-Manhaj Al-Sadīd Fi Syarh Kifāyat Al-Murīd, . Al-Jazāir: Dār al-Hudā, n.d.

Abū al-Hasan Al-Asy'ari. Risalah Ahl Al-Śagr. Cairo: Mathba'ah al-Taqaddum, 1987. Abū al-Hasan al-Asy'arī. Maqalat Al-Islāmiyyīn . Beirūt: Maktabah Al Așriyyah, 1990.

Abū Bakar Muhammad bin al-Husain al-Ajurrī al-Baghdādī. Al-Syariah. Riyāụ: Dār al-Waṭ, 1998.

Abū Bakr Muhammad ibn al-Ḥasan Ibnu Furāk. Mujarrad Maqalat Al-Syekh Abī AlHasan Al-A'syārī. Bairūt: Dār al-Masyriq, 1987.

Abū Bakr Muḥammad ibn Ṭayyib ibn al-Baqillani. Al-Tamhīd. Bairūt: al-Maktabah al-Syarqiyyah, 1958.

Abū Ḥāmid al-Gazālī. Al-Maqshad Al-Asna Fì Syarh Al-Asmā' Al Husnā. Bairūt: Dār ibn Hazm, n.d.

Abū Ḥāmid al-Ghazālī. Qawāid Al- 'Aqāid. Beirūt: Ālim al Kutub, 1985.

Adnin, Adnin, and Muhammad Zein. "Epistemologi Kalam Asy'ariyah dan AlMaturidiyah." Al-Hikmah: Jurnal Theosofi Dan Peradaban Islam 2, no. 1 (2020).

Al-Baijurī. Tuhfat Al-Murìd 'Ala Jauharat Al-Tauhid. 1st ed. Al Qahirah: Dār alSalām, 2002.

Al-Bukhari, Muhammad. Sahih Al-Bukhari. Dar Ul-Hadith, 1978.

Al-Imām Al- Ḥāfiz Abī Bakr Aḥmad ibn al Ḥusain Al-Baihaqī. Al-Asmā' Wa Al-Ṣifāt. Dār Al Syuhdā, 1340.

al-Imām al-Gazālī. Al-Iqtiṣād F̄̄ Al-I’tiqād. 1st ed. Al-Qāhirah: Dār al-Bașāir, 2009.

Al-Imām Muhyi al-Sunnah Abī Muhammad al Husain Ibn Mas'ūd Al-Baghawī. Ma'alim Al-Tanzil. Riyāụ: Dār al-Ṭayyibah, 1989.

Al-Sanūs̄̄, Abū Abdillāh Muḥammad bin Yūsuf. Syarah Ummul Barahīn. Libanon: Dār al Kutub al- Ilmiah, 2009.

Al-Syahrastani, Muhammad Ibn Abd al. "Karim, Al-Milal Wa Al-Nihal." Jilid I, Kairo: Mustafa al-Babi al-Halabi Wa Awladuhu, 1967.

Al-Żahabī. Al- 'Uluw Lī 'Ālī Al-Gaffār. Riyāḍ: Maktabah Aḍ̂ā al Salaf, 1995.

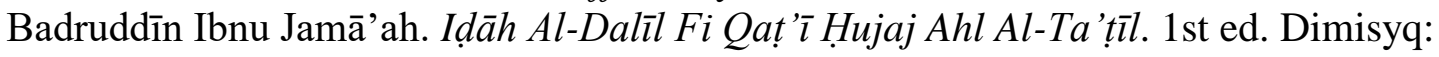
Dār Iqrā', 2008.

Fais̄āl Ibn Qazār al-Jāsim. Al-Asyā'irah F̄̄ Mizān Ahl Sunnah. 1st ed. Kuwait: alMabarratu al-Khairiyyah li Umūr al-Qur'ān wa al-Sunnah, 2007. 
Fakhruddin Al-Razi. Asās Al-Taqdīs. al-Qāhirah: Maktabah al-Kullīyāt alAzhāriyyah, 2001.

Hasibuan, Hadi Rafitra. "ALIRAN ASY'ARIYAH (Kajian Historis Dan Pengaruh Aliran Kalam Asy’ariyah).” Jurnal Ilmiah Al-Hadi 2, no. 2 (2018): 433-41.

Hasyim, Muhammad Syarif. "Al-Asy'ariyah (Studi Tentang Pemikiran Al-Baqillani, Al-Juwaini, Al-Ghazali)." HUNAFA: Jurnal Studia Islamika 2, no. 3 (2005): 209-24.

Hazm, Ibnu. Al-Fashl Fi Al-Milal Wa Al-Ahwa'wa Al-Nihal, Vol. IV (Beirut. Vol. 5. Maktabah al-Salām al-Alamiyah, n.d.

https://uqu.edu.sa/saomairi/App/CV. “السيرة الذاتية سلطان العميري," n.d.

Ibnu Abdil Bar. Al-Tamhìd, 1979.

Ibnu Hajar al-'Asqālanī. Fath Al-Bari Syarh Shahih Al-Bukhari. Maktabath alSalafiyyah, n.d.

Ibnu Hajar Syihabuddān Abū Al-Fadhl Aḥmad bin Alī bin Muḥammad bin Ḥajar. Lisan Al-Mizan. Beirūt: Muassasah al-A'lamī, 1971.

Ibnu Taimiyah. Dar'u Al-Ta'arudh Baina Al-Aql Wa Al-Naql. Riyadh: Al Jamiah Al Imam Muhammad Ibn Sa'ud Al Islamiyah, 1991.

Ibnu Taimiyyah. Minhāj Al-Sunnah Al-Nabawiyah F̄̄ Naqḍ Al-Kalām Al Syiah AlQadariyyah. Riyadh: Jāmiah al-Imām Muhammad ibn Saūd al-Islāmiyyah, 1986. Ilhamuddin, Ilhamuddin, and Muhammad Lathief Ilhamy Nasution. "Teologi Islam

Warisan Pemikir Muslim Klasik," n.d.

Imām al- Haramain Al Juwainī, Al. Kitāb Al-Irsyād Ilā Qawāti' Al-Adillah F̄̄ Usīùl Al-

I’tiqād. 1st ed. Al Qahirah: Maktabah Al Saqāfah al Diniyyah, 2009.

Imam al-Lalikā'̄i. Syarh Ushul I'tiqad Ahlis Sunnah Wal Jamaah. Iskandariyah: Dār al-Bas̄īrah, n.d.

Ismā'îl Ibn Yahyāā Al-Muzanī. Syarh Al-Sunnah, n.d.

Ismail bin Musā bin Uṡmīn al-Hāmidī. Hawas̄̄ 'Ala Syarh Al-Kubrā Li Al-Sanusī AlTilmisānī. Mișr: Maṭbah Musțafā al Bānī al-Halabī wa Auladuhū, 1936.

Istiqamah, Muhammad. "Kritik Teologi Salafiyah Terhadap Ahli Kalam Dalam Memahami Sifat-Sifat Allah." NUKHBATUL'ULUM: Jurnal Bidang Kajian Islam 6, no. 1 (2020): 77-104.

Muhammad Sa'īd Ramaḍān Al-Būṭī. Kubra Al-Yaqīniyyāt Al-Kauniyyah. Damaskus: Dār al-Fikr, 1982.

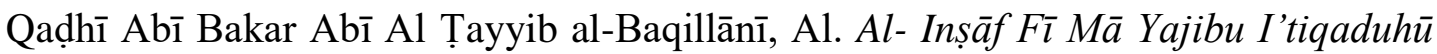
Wa La Yajuzu Al-Jahlu Bih̄̄. 2nd ed. -: Dār al-Tayfīq Al Namūżajiyyah, 2000.

Saifuddīn al-Amidī. Gāyāt Al-Marām Fi 'Ilm Al-Kalām. Al-Qāhirah: Lajna al-Turās̀ al-Islāmiyah, 1981.

Sayyid Syarīf 'Alī Ibn Muhammad al-Jurjānī. Syarh Al-Mawāqif Lì Al-Qād̄̄ 'Adu AlDìn Abdurrahmānn Al-'Ijī. 3rd ed. Bairūt: Dār Kutub Al Ilmiah, 1998.

Sulțān Al-Umairī. Idạât F̄̄ Al-Tahrīr Al- 'Aqad̄̄. 1st ed. Markaz Tafakkur Li Al-Buhus wa Al-Dirasāt, 2014.

Syaikh al-Islām Aḥmad ibn al Ḥalīm Ibnu Taimiyah. Al-Tis 'iniyyah. 1st ed. Riyāḍ: Maktabah al Ma'ārif li al-Nasyr wa al tauzīe 1999.

Taimiyah, Ibnu. Naqdh Asas Al-Taqdis. Makkah: Mathba'ah al-Hukumah, n.d.

Taimiyyah, Taqiyuddīn Abu al-Abbās Ahmad bin Abdu al-Halīm Ibnu. Majmu' AlFatāwa. Juz 24. Madinah: Majma’ al-Malik Fahd, 1995. 
NUKHBATUL 'ULUM: Jurnal Bidang Kajian Islam

Vol. 7, No. 2 (2021): 298-317

Website: https://journal.stiba.ac.id

ISSN : 2685-7537 (online); 2338-5251 (Printed)

Thabari, Ath, and Ibnu Jarir. "Tafsir A1 Thabari." Juz II, Beirut: Daar Al Fikr, 1954. Ulum, Bahrul. "Dinamika Ilmu Kalam Sunni." EL-BANAT: Jurnal Pemikiran Dan Pendidikan Islam 6, no. 2 (2016): 22-33.

Ya'lā', Al-Qaḍī Abū. Kitāb Al-Mu'tamad F̄̄ Ușuluddīn. Bairūt: Dār al-Masyriq, 1974. Zed, Mestika. Metode Peneletian Kepustakaan. Yayasan Obor Indonesia, 2004. 